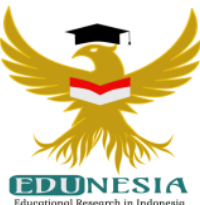

\title{
Analysis of Distance Learning Implementation from the Teacher's Perspective (Case Study: Sdit Al Iman Bintara)
}

\author{
Tissa Maharani \\ Department of Information Technology, Gunadarma University, Indoensia \\ Corresponding Email: tissa@staff.gunadarma.ac.id, Phone Number:0812 xxxx xxxx
}

\section{Article History: \\ Received: June 12, 2021 \\ Revised: July 01, 2021 \\ Accepted: July 03, 2021 \\ Online First: July 08, 2021}

\section{Keywords:}

Analysis, Distance

Learning, Teacher's

Perspective.

Kata Kunci:

Analisis, Pembelajaran

Jarak Jauh, Perspektif

Guru.

\section{How to cite:}

Maharani, T. (2021). Analysis of Distance Learning Implementation from the Teacher's Perspective (Case Study: Sdit Al Iman Bintara. Edunesia: Jurnal Ilmiah Pendidikan, 2 (3): 619-627.

This is an open access article unde the $C C-B Y-N C-N D$ license
Abstract: This study aims to analyze and explain how the implementation of distance learning during the COVID-19 pandemic by first graders teacher. How the learning process was held, what information and communication technology was used, how was the preparation, what obstacles are faced by the respondents. The research method used a case study of descriptive qualitative approach with a phenomenological paradigm. The research subject is the first grade teacher of SDIT Al Iman Bintara. Data collection techniques using observation and questionnaires conducted online. Data analysis used descriptive statistics, with stages of data reduction, data presentation and conclusions. The result of the research is that the implementation of distance learning at SDIT Al Iman Bintara is running well according to the policies and technical implementations made by the school. The most widely used information and communication technologies during distance learning are Zoom, Edmodo and WhatsApp. The use of information and communication technology makes it easier for respondents in teaching activities, because previously respondents had attended special training from schools. Although $100 \%$ of respondents are used to using it every day, there are still obstacles that occur, such as internet signals that are not supported (disconnected/disappeared) or signal struggles with fellow teachers at school; internet packages for educators from the government that are not enough to use for one month when teaching from home; the material presented is less understandable by students, especially when there is a signal problem, which makes students no longer want to continue learning even though the signal is smooth again.

Abstrak: Penelitian ini bertujuan untuk menganalisis dan menjelaskan seperti apa pelaksanaan pembelajaran jarak jauh selama pandemi COVID 19 oleh guru siswa kelas satu. Seperti apa proses belajar yang dilakukan, teknologi informasi dan komunikasi apa yang digunakan, bagaimana persiapan dari pihak guru, kendala apa saja yang dihadapi oleh responden. Metode penelitian yang digunakan adalah pendekatan kualitatif deskriptif jenis studi kasus dengan paradigma fenomenologi. Subjek penelitian adalah 10 guru kelas satu SDIT Al Iman Bintara. Teknik pengumpulan data menggunakan teknik observasi dan kuesioner yang dilakukan secara online. Analisis data menggunakan statistik deskriptif, dengan tahapan reduksi data, penyajian data dan kesimpulan. Hasil penelitian adalah pelaksanaan pembelajaran jarak jauh di SDIT Al Iman Bintara berjalan dengan baik sesuai kebijakan dan teknis pelaksanaan yang dibuat oleh sekolah. Teknologi informasi dan komunikasi yang paling banyak digunakan selama pembelajaran jarak jauh adalah Zoom, Edmodo dan WhatsApp. Penggunaan teknologi informasi dan komunikasi tersebut memudahkan para responden dalam aktivitas mengajar, karena sebelumnya responden telah mengikuti pelatihan khusus dari sekolah. Walaupun $100 \%$ responden sudah terbiasa menggunakannya setiap hari, tetap saja masih ada kendala yang terjadi, seperti sinyal internet yang kurang mendukung (putus-sambung/hilang-timbul) ataupun rebutan sinyal dengan sesama guru di sekolah; paket internet untuk pendidik dari pemerintah yang tidak cukup untuk digunakan selama satu bulan ketika mengajar dari rumah; materi yang disampaikan kurang bisa dipahami oleh siswa, apalagi ketika terjadi kendala sinyal, yang membuat siswa tidak mau lagi melanjutkan belajar walaupun sinyal sudah lancar kembali. 


\section{A. Introduction}

Information and communication technology has a role in various fields, one of which is in the field of education. The world of education is required to always adapt to technological developments in improving the quality of education, especially in the learning process (Budiman, 2017).

This role has become increasingly important since COVID 19 was a pandemic from March 2020. This pandemic has forced face-to-face learning activities in schools to be completely stopped, and moved to cyberspace, in accordance with the ministerial decree for the prevention of COVID 19 issued on March 9, 2020, by the Minister of Education and Culture Nadiem Makarim, called Distance Learning. This distance learning does not require students to come to school so it requires information and communication technology for its implementation (Kamil, 2020).

In reality, distance learning is still difficult to implement at the start of the pandemic. Because it is an educational transformation that requires educators and students to interact online learning, so that it has very tough opportunities and challenges for teachers and students (Suhendro, 2020).

Several obstacles and difficult challenges such as lack of mastery of technology, additional cost of internet quota, additional work for parents in accompanying children to study, the lack of communication and socialization between students, teachers and parents, and teacher's unlimited working hours, making distance learning less than optimal (Ali, 2020). Some schools don't even make rules or regulations related to the technical implementation of learning, so many teachers are confused about it (Mamluah \& Maulidi, 2021). Not to mention problems related to infrastructure such as electricity and internet networks (Rizal, 2020).

Until today, distance learning is still being implemented in almost all schools in Indonesia, including the Al Iman Bintara Integrated Islamic Elementary School (SDIT) located in West Bekasi sub-district, Bekasi City, West Java. The implementation of distance learning at SDIT Al Iman Bintara has been going on for almost 1 year, starting from July 2020 until now. As an Islamic school with A accreditation, SDIT Al Iman is one of the leading private schools that combines religion and science, to create a generation of Muslims who have noble character and achievement as the expectations of the people, as stated in the school's vision and mission.

This paper analyzes and explains how the implementation of distance learning during the COVID-19 pandemic by first-grade teacher teachers, who teach students who have just graduated from kindergarten and immediately feel the difference in the learning process from kindergarten to elementary school with the distance learning system for the first time. What kind of learning process is carried out, what information and communication technology is used, how is the preparation from the teacher, what obstacles and challenges are faced by first grade teachers in its implementation.

\section{B. Method}

The method used in this study uses a descriptive qualitative approach with the type of case study research with a phenomenological paradigm. According to Tanzeh (2011) qualitative research is research that produces descriptive data in the form of written or spoken words from people and observable behavior. According to Sugiyono (2017), the purpose of qualitative research is none other than to find out some facts and information in 
the field, either in the form of an explanation of the description of the research subject or in the form of data and images that can support research results. So that it can be found a solution to the problem of the object under study naturally. This qualitative research approach is assessed according to the needs of the researcher, because basically the problems that occur are only about the object of research and the facts received are adjusted to what is being studied.

According to Rahardjo (2017), in the view of the phenomenological paradigm, what is visible or invisible is essentially not something real. It's just a reflection of what's inside. The task of the case study researcher is to explore something that is not visible to become visible knowledge. So it can also be interpreted, a case study as a process of studying or understanding a case and at the same time looking for the results.

The research was conducted from July 2020 to June 2021, using observation techniques and online questionnaires to collect data, as well as other research literature studies. The questionnaire was created using Google Docs and provided a link to the questionnaire via the WhatsApp application to the respondents with questions related to the research objectives. Analysis of the data collected using descriptive statistics, with the stages of data reduction, data presentation and conclusions (Sugiyono, 2017).

The research subjects were 10 first grade teachers of SDIT Al Iman Bintara, who were given initials for confidentiality purposes. The researcher wanted to analyze and describe the implementation of distance learning at SDIT Al Iman Bintara from the perspective of a first grade teacher. What kind of learning process is carried out, what information and communication technology is used, how is the teacher's preparation, what obstacles and challenges are faced by first grade teachers in its implementation, especially when teaching first grade students who have just graduated from kindergarten, and are experiencing changes of learning process from kindergarten to elementary school.

Table 1. Respondent profile

\begin{tabular}{llll}
\hline Initial & Gender & Age & Education \\
\hline A1 & Female & 28 & Bachelor degree \\
A2 & Female & 31 & Bachelor degree \\
A3 & Male & 32 & Bachelor degree \\
A4 & Female & 36 & Bachelor degree \\
A5 & Female & 26 & Bachelor degree \\
A6 & Female & 36 & Bachelor degree \\
A7 & Male & 26 & Bachelor degree \\
A8 & Female & 24 & Bachelor degree \\
A9 & Female & 35 & Bachelor degree \\
A10 & Female & 25 & High School graduate \\
\hline
\end{tabular}

\section{Result and Discussion}

It has been almost a year, from July 2020 to June 2021 distance learning is being carried out in the first grade of SDIT Al Iman Bintara. This program was implemented after the Minister of Education and Culture Nadiem Makarim issued a policy to reduce face-toface activities in order to break the chain of spread of COVID 19 in Indonesia. 
In the concept of electronic learning, distance learning is not novelty, but because it is carried out simultaneously and seems 'sudden' without proper preparation, this program needs special attention. According to Contesa (2020), the distance learning concept that suggested by the government is to encourage all students to study at home with parental supervision. The implementation of teaching and learning activities uses methods that have been made by each school. Activities that refer to children's behavior, attitudes and morals must be reported by parents every day through videos or photos.

After the ministerial decree from Minister of Education and Culture for the implementation of online learning, schools usually have their own policies or technical regulations to regulate the distance learning process. However, some schools do not make rules or regulations related to the technical implementation of learning, so many teachers are confused about the technical distance learning.

\section{Distance Learning Implementation System}

SDIT Al Iman is a school that makes the regulation of technical implementation for this distance learning program. The technical implementation of daily learning activities or called the daily program is made by schools and is mandatory for all teachers, but for the method or media used, it is entirely up to the teaching teacher. Each Teacher Working Group agrees on the methods and media used, adapted to the student's learning style.

In the daily program, each subject is required to do face-to-face using Zoom. Every day students study three subjects. Teaching and learning activities begin at 07.15 which are opened by the homeroom teacher using Zoom for 30 minutes. Then continued by the subject teacher using Zoom according to the study schedule for 50 minutes. Rest time twice for 20 minutes each. Teaching and learning activities ended at 11.40.

\section{Information and Communication Technology Used}

According to Dhawan (2020), before proposing and adopting e-learning tools or technologies, it is necessary to consider the pros and cons. There are several factors that influence the choice of a particular technology, such as security features, laboratory availability and conditions, internet speed, internet access, and the digital literacy level of the beneficiary. For e-learning to be effective in today's difficult times, institutions need to concentrate on using technology more effectively, i.e. using technology that has the lowest procurement and maintenance costs, but can effectively drive the educational process.

At SDIT Al Iman Bintara, the information and communication technology selected and used by respondents for distance learning in first grade are as follows :

1. $100 \%$ of respondents use the Zoom application to have face-to-face online with students.

2. $100 \%$ of respondents use Edmodo for exams, daily assessments, or practice questions.

3. $100 \%$ of respondents use the WhatsApp application. Group chat to communicate with student guardians regarding information related to the implementation of learning, video call for Tahsin Qur'an subjects, Voice Note for Bina Fiqh subjects, Islamic Religious Education and English, as well as Video for subjects that requires the collection of assignments in the form of videos.

4. $50 \%$ of respondents use the Quizizz for fun alternative practice questions. 
5. $50 \%$ of respondents use video-making applications such as Kinemaster, Inshot, Viva Video, Bandicam, Filmora, or screencast-o-matic for making learning materials.

6. $80 \%$ of respondents use YouTube for additional material or save videos of learning materials that have been made.

7. $10 \%$ of respondents use the Canva site to enhance the appearance of their presentation.

It can be concluded that the most used information and communication technologies by 10 respondents during distance learning are Zoom, Edmodo and WhatsApp. In the second position, 8 respondents use YouTube. In the third position, 5 respondents used Quizizz and application to make videos. The last position, 1 respondent uses Canva.

A total of $10 \%$ of respondents answered Neutral, 50\% answered Agree, and $40 \%$ answered Strongly Agree on the statement "using information and communication technology makes it easier for me to teach online". It can be interpreted that 1 respondent feels so-so in the use of information and communication technology during distance learning, and 9 respondents feel that the information and communication technology used makes it easier to teach during distance learning.

\section{Teacher Readiness and Adaptation}

\section{Teacher Conditions Before the Implementation of Distance Learning}

Before distance learning took place, $100 \%$ of respondents used computers/laptops as technology to assist in completing school assignments such as processing grades, making questions, making study materials, reports, and so on. As many as $90 \%$ of respondents have used information and communication technology such as YouTube, Edmodo, Canva, video editing applications, and Power Point for teaching and learning activities. As many as 10\% of respondents do not have experience studying and using information and communication technology that used for distance learning. It can be concluded that, 10 respondents use computers/laptops to complete school assignments, 9 respondents have used some of the information and communication technology used for distance learning. Only 1 respondent had no experience of using it at all before distance learning was implemented.

Out of 10 respondents, only $20 \%$ of respondents had experience of distance teaching before distance learning was implemented. As many as $90 \%$ of respondents attended special training from school before doing distance learning, while $10 \%$ of respondents did not take special training from school, because he just started teaching in second semester. It can be concluded that, only 2 respondents have teaching experience distance before the implementation of distance learning. A total of 9 respondents had attended special training facilitated by the school prior to the implementation of distance learning, and 1 respondent had not attended the training.

\section{Teacher Conditions During the Implementation of Distance Learning}

From the results of the questionnaire, only 30\% of respondents answered Agree to the questionnaire statement "I am very enthusiastic about teaching with the distance learning system". while 70\% of respondents answered Neutral. It can be concluded that, only 3 respondents are very enthusiastic about teaching online, 7 respondents feel so-so.

Currently, as many as $100 \%$ of respondents are accustomed to using information and communication technology that used during distance learning. $60 \%$ of respondents feel skilled and master the technical use of information and communication technology used, 
$10 \%$ are very skilled and mastered, and $30 \%$ answered Neutral or ordinary, but $90 \%$ still find it difficult when using it. It can be concluded that, even though respondent are used to using it every day, there are still difficulties that occur, especially when WiFi is not friendly, or an error occurs, for example.

As many as $70 \%$ of respondents answered Strongly Agree and Agree to the statement "I feel overwhelmed in making learning materials", 20\% answered Neutral, and $10 \%$ answered Agree. It can be interpreted that 7 respondents do not feel overwhelmed when making materials, 2 respondents feel so-so, and 1 respondent feels overwhelmed.

As many as $40 \%$ of respondents answered Neutral, $40 \%$ answered Agree, and $20 \%$ answered Strongly Agree to the statement "I feel that the duties and work during distance learning are more numerous than teaching face-to-face at school (offline)". It can be interpreted that 6 respondents feel that the workload increases during the implementation of distance learning compared to offline teaching at school, only 4 respondents feel that it is so-so.

Of the 10 respondents, $100 \%$ did not use the learning facilities provided by the government such as the Ruang Guru, Rumah Belajar, Meja Kita, Sekolahmu, Zenius, Google for edu, Kelas Pintar, Quipper, and others for distance learning at SDIT Al Iman. According to respondents, it is caused by the following things:

1. The learning facilities provided do not include the subjects being taught, such as Tahsin Qur'an.

2. It is more effective to use Zoom for face-to-face with students, because it is easier to use and to bond more with students.

3. Not familiar with the learning facilities provided by the government.

4. Difficult to join, and some are usually paid.

5. Do not know about the information on the learning facilities.

6. Less effective for use during distance learning.

7. The information and communication technology used today is sufficient to support distance learning in first grade. If more is used, it can make it difficult for first graders to learn.

\section{Teacher Condition After Distance Learning (Almost) Completed}

Currently the learning activities have been completed, and the students are carrying out the Year-End Assessment for grade promotion, so the daily program is no longer available. $60 \%$ of respondents who served as homeroom teachers only met face-to-face using Zoom for exam preparation from 7.15 to 8.00 am for five days from 7 June - 11 June 2021 . $100 \%$ of respondents used Edmodo for the exam. The use of information and communication technology is not as frequent as when carrying out teaching and learning activities.

As many as $20 \%$ of respondents answered Strongly Disagree, $30 \%$ of respondents answered Disagree, 30\% answered Neutral, and 20\% answered Agree to the statement "when I think about tasks and work it sometimes makes me difficult to sleep". It can be interpreted that 5 respondents feel it is not difficult to sleep when thinking about tasks and work, 3 respondents feel so-so, and only 2 respondents feel that sometimes it is difficult to sleep when thinking about unfinished tasks and work.

A total of $10 \%$ answered Neutral, 30\% answered Agree, and $60 \%$ answered Strongly Agree on the statement "I prefer to teach face-to-face at school (offline) than distance 
learning". It can be interpreted that as many as 9 respondents prefer the face-to-face system at school than distance learning, only 1 respondent feels it is so-so.

As many as $60 \%$ of respondents answered Disagree, and $40 \%$ answered Neutral to the statement "I find it difficult to teach during distance learning". It can be interpreted that 6 respondents do not find it difficult to teach during the implementation of distance learning, and 4 respondents feel so-so.

A total of $10 \%$ of respondents answered Strongly Disagree, $60 \%$ answered Disagree, $10 \%$ answered Neutral, and $20 \%$ answered Agree to the statement "I am very uncomfortable teaching which requires me to use a computer/laptop or information and communication technology during the implementation of distance learning". It can be interpreted that 7 respondents feel comfortable using information and communication technology during distance learning, 1 respondent feels so-so, and 2 respondents feel very uncomfortable..

As many as $20 \%$ of respondents answered Neutral, 50\% answered Agree, and 30\% answered Strongly Agree on the statement "I feel distance learning is not as effective as faceto-face at school or offline". It can be interpreted that 8 respondents feel that the implementation of distance learning is not as effective as face-to-face at school / offline, the remaining 2 respondents feel that it is so-so.

A total of $10 \%$ of respondents answered Strongly Disagree, $50 \%$ answered Disagree, $30 \%$ answered Neutral, and 10\% answered Strongly Agree on the statement "I find it difficult to communicate with students and parents during distance learning". It can be interpreted that as many as 6 respondents did not have difficulty communicating with students and parents during the implementation of distance learning, 3 respondents felt so-so, 1 respondent found it difficult to communicate.

As many as $30 \%$ of respondents answered Disagree, 50\% answered Neutral, $10 \%$ answered Agree, and 10\% answered Strongly Agree on the statement "I feel tired with online teaching activities". It can be interpreted that 3 respondents feel not tired with teaching activities during distance learning, 5 respondents feel so-so, and 2 respondents feel tired.

\section{Obstacles And Challenges That Happened}

During the distance learning lasted almost 1 year, the following are the obstacles and challenges faced by the respondents:

1. $90 \%$ of respondent think that internet signal is a main problem.

2. $40 \%$ of respondent think that the internet package assistance for educators from the government is not enough to be used for a month of online teaching.

3. $30 \%$ of respondent think that the learning material presented is less understandable by students.

4. $20 \%$ of respondent thought that they were not familiar with information and communication technology before online learning.

5. $10 \%$ of respondents think that they are not enthusiastic about teaching.

6. $10 \%$ of respondents think that families are getting less attention because they are more busy preparing for teaching activities.

7. $10 \%$ of respondents think that the very short learning time makes learning less than optimal.

8. $10 \%$ of respondents think that the time to prepare material is longer than offline teaching, and students' achievement targets are neglected.

It can be concluded that the main obstacle that occurs during the implementation of distance learning is the internet signal, either caused by an unsupportive signal (intermittent) 
or signal struggle with fellow teachers at school. The second obstacle is the internet package for educators from the government which is not enough to be used for one month when teaching from home due to a reduction in the quota in early 2021. The third obstacle, even though they have done their best to make learning materials, still the material delivered is not quite understandable by students. Especially when there is a signal problem, which immediately puts the students in a bad mood, no longer willing to continue learning even when the signal is smooth again. Of course this has an impact on students' understanding of the learning material.

\section{Conclusion}

From the results of research conducted on the implementation of distance learning in the first grade of SDIT Al Iman, it can be concluded that :

1. The distance learning implementation system conducted by SDIT Al Iman for the first grade has been running well for almost a year, although it seems sudden. Implementation is in accordance with the policies and technical implementation made by the school.

2. The most widely used information and communication technologies during distance learning in the first grade of SDIT Al Iman Bintara are Zoom, Edmodo and WhatsApp. Followed by YouTube, Quizizz and video creation applications, and Canva.

3. The use of information and communication technology facilitates the respondents in teaching activities.

4. Respondents always use computers/laptops before distance learning, 90\% have used some of the same information and communication technology used during distance learning, and have received special training before the implementation of distance learning.

5. Although $100 \%$ of the respondents are used to using information and communication technology every day, there are still obstacles that occur as mentioned earlier, but this does not dampen the enthusiasm of the respondents to teach.

The suggestions for distance learning to take place better in the future are :

1. The use of information and communication technology for distance learning is now sufficient for first graders, if it is added it will confuse students and parents.

2. Provision of better and more stable WiFi facilities so that teachers are not too constrained by the signal.

3. Procurement of more complete tools to support the making of learning material videos.

4. Conducting special training on how to make presentations of material more interesting so that students are more enthusiastic about learning.

5. Procurement of student attendance applications to facilitate teachers when absent whenever possible.

More intense communication between schools represented by teachers, students and guardians of students, so that the implementation of distance learning is even better at SDIT Al Iman Bintara. 


\section{Acknowledgment}

The author would like to express her deepest gratitude to all contributors and respondents at SDIT Al Iman Bintara; The Principal, the Curriculum Section, and the first grade teachers, who have given their time for this research, so that it can be written down. Jazaakumullah khoiran katsir.

\section{References}

Ali, M. (2020). Studi Eksploratif Dampak Pandemi COVID-19 Terhadap Proses Pembelajaran Online di Sekolah Dasar Negeri Ambender 01. Seminar Nasional Hasil Pengabdian Kepada Masyarakat (SENIAS) - Universitas Islam Madura

Budiman, H. (2017). Peran Teknologi Informasi Dan Komunikasi Dalam Pendidikan. AlTadzkiyyah: Jurnal Pendidikan Islam, Volume 8 Nomor 1.

Contesa, D. (2020). Hubungan Orang Tua dengan Minat Belajar Siswa pada Masa Covid-19. Retrieved from https://mahasiswaindonesia.id/hubungan-orang-tua-denganminat-belajar-siswa-pada-masa-covid-19/.

Dhawan, S. (2020). Online Learning: A Panacea in the Time of COVID-19 Crisis. Journal of Educational Technology Systems, Volume 49 Nomor 1, hal. 5-22.

Kamil, I. (2020). Kilas Balik Pembelajaran Jarak Jauh Akibat Pandemi Covid 19. Retrieved from https://nasional.kompas.com/read/2020/09/03/10063201/kilas-balikpembelajaran-jarak-jauh-akibat-pandemi-covid-19?page $=$ all.

Mamluah, S.K., \& Maulidi, A. (2021). Pembelajaran Jarak Jauh (PJJ) di Masa Pandemi COVID-19 di Sekolah Dasar. Jurnal Basicedu, Volume 5 Nomor 2.

Rahardjo, M. (2017). Studi Kasus dalam Penelitian Kualitatif : Konsep dan Prosedurnya. Unpublished. Materi Kuliah Metode Penelitian, Sekolah Pascasarjana Universitas Islam Negeri Maulana Malik Ibrahim Malang, Januari.

Rizal, J.G. (2020). Hari Pertama Sekolah, Pembelajaran Jarak Jauh yang Penuh Tantangan. Retrieved from https://www.kompas.com/tren/read/2020/07/13/141000265/hari-pertamasekolah-pembelajaran-jarak-jauh-yang-penuh-tantangan?page=all.

Sugiyono. (2017). Metode Penelitian Kuantitatif, Kualitatif, dan RED. Bandung: Alfabeta

Suhendro, E. (2020). Strategi Pembelajaran Pendidikan Anak Usia Dini di Masa Pandemi Covid-19. Jurnal Golden Age : Jurnal Ilmiah Tumbuh Kembang Anak Usia Dini, Volume 5, Nomor 3, hal. 133-140, September.

Tanzeh, A. (2011). Metodologi Penelitian Praktis. Yogyakarta: Teras. 